\title{
Opinion on Covid-19 as Perceived and Experienced by Africans
}

\author{
Paulin Bertr and NGUINA EKEME* \\ Faculty of Economics and Management, the University of Yaoundé II, Cameroon
}

*Corresponding author: Paulin Bertrand NGUINA EKEME, Faculty of Economics and Management, the University of

Yaoundé II, Cameroon

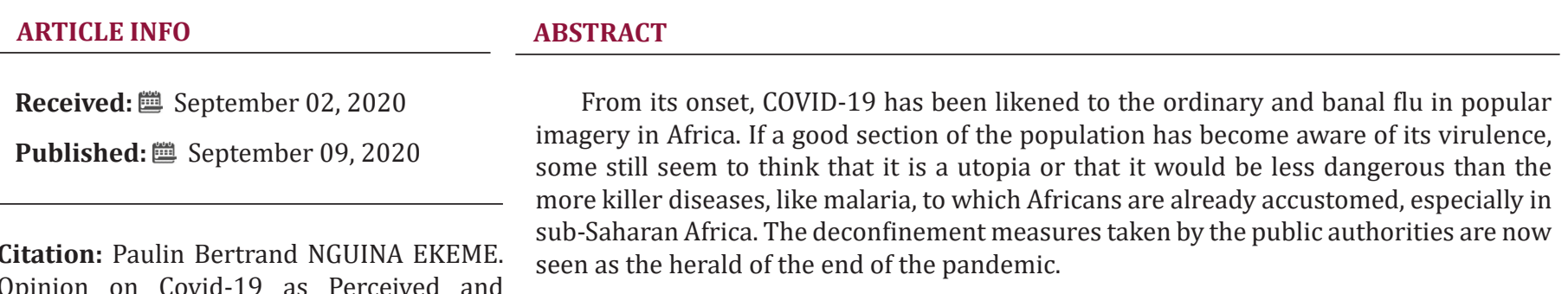

Experienced by Africans. Biomed J Sci \&

Tech Res 30(2)-2020. BJSTR. MS.ID.004922.

\section{Opinion}

Our opinion will focus on how people on the African continent perceive and experience the 2019 coronavirus disease (COVID-19) since it was first reported in Wuhan, China, on December 31, to the present day. We could characterize it in three main periods:

\section{From the Onset of COVID-19 to the Registration of the First Cases on the Continent}

The emergence of the novel coronavirus in China was seen as trivial information in Africa. It was thus thought that it was, without doubt, a seasonal flu, and therefore transient, or caused by the great pollution experienced by this country due to its excessive industrialization (immense clouds of pollution which often make breathing difficult, thus requiring the wearing of masks to filter the air to breathe). But, from the period of February to midMarch 2020, the outbreak of the pandemic in Europe began to cause concern in Africa because of migratory movements with the continents already affected. The appearance, in February 2020, in Egypt of the first case, led the World Health Organization (WHO) to call on Africa to prepare for the worst in the face of the COVID-19 pandemic, because its health system weak was not able to cope with it [1].

However, in the African conception, the novel coronavirus was a disease that could be understood and treated like all other mild seasonal influenza (which appears during periods of humid climates). Moreover, in sub-Saharan Africa, seasonal influenza is not considered to be a real disease in the face of diseases that are decimating populations such as malaria, viral hepatitis, waterborne diseases (typhoid fever, cholera, etc.). In addition, all these diseases caused manifesting themselves, at the level of symptoms, as soon as they appear, by fever (as with COVID-19), most Africans have considered that taking certain decoctions such as herbal teas or residing in hot climatic zones would save them from this pandemic.

\section{The Period of the Pandemic Outbreak}

From the second half of March, African governments and populations began to realize the dangerousness of the pandemic with the multiplication of cases on the continent. Barrier measures have thus been taken such as the closing of borders, schools, confinement of populations, etc. The alert was perceptible, although a frank of the population believes, and this until today, that it is a made up disease, a utopia. But the deaths in some families have made some people realize the evil. An accusing finger was then placed on the African diaspora who brought back COVID-19, when they should have protected their continent by staying in the West for their care. This has led to its stigmatization, also causing the 
fact that some patients who had been identified and isolated in specialized structures for the purposes of treatment spread among the population, thus promoting the community spread of the virus.

In addition, this has resulted in the desertion of health facilities by populations suffering from other diseases, thus strengthening the practice of self-medication and alternative means of healing (clandestine health facilities, charlatans, churches, etc.). This period is also marked by the soaring prices of certain drugs and foods containing vitamin $\mathrm{C}$, because they are considered to be "innovative" solutions against COVID-19. It was an opportunity for some Africans to develop their entrepreneurial spirit by offering protective masks, hand washing devices and even "miracle" healing potions of all kinds.

However, it can be assumed that the estimated predictions in terms of death rates have not been confirmed, and we can assume that this is due to some contextual factors, including the fact that:

a) Africans seem to have developed a resistant immune system due to their habit of the various diseases mentioned above (malaria, hepatitis, etc.);

b) Traditional medicine, although not really recognized, because it does not meet all conventional pharmaceutical scientific protocols, has played a big role in the treatment of COVID-19, although some results remain mixed. But in the popular imagery, psychologically speaking, it has genuinely helped cure a large number of cases.

c) Self-medication has also played a mixed role in that since the symptoms of COVID-19 are similar to those of malaria, quinine-based drugs have been the subject of medical prescription (while debates on the scientific effectiveness of hydroxychloroquine was poignant among the luminaries of the medical world out of Africa: mainly in Europe and United States of America) or self-administration as a preventive measure by populations or by people who showed signs of COVID-19.

\section{The Period of the Start of the Pandemic}

The gradual easing of containment measures as of May in most African countries has been understood as recognition of the end of the pandemic. The illustrative case is that of Cameroon where the authorities have decided to reopen drinking establishments, restaurants and places of leisure beyond 6 p.m. Despite the stated obligation to wear a protective mask and social distancing, the vast majority of populations no longer comply with these requirements, despite multiple calls to order from the state authority. Indeed, if these decisions were taken out of a concern for the preservation of fragile African economies, one could suppose that they were also part of a concern for the preservation of social peace (we have recently seen state institutions overthrown in cause of popular uprisings due to the increase in basic foodstuffs, persistent unemployment....). It seems to us, in view of the current situation, that if the state authorities have decided on barrier measures to fight COVID-19, the deconfinement of the populations is now done by themselves.

In conclusion, the factors that structure the perception and experience of COVID-19 in Africa relate to the fact that it was first understood as a common flu not considered a real disease in the African context. If its dangerousness has been integrated with the taking of the barrier measures decreed by the public authorities, their relaxation is now understood as the declaration of the end of the pandemic. Especially also because the hecatomb predicted in terms of expected deaths in millions did not occur, probably because of immune predispositions created by plagues such as malaria and other serious diseases to which Africans are accustomed, consumption traditional products and preventive self-medication of products treating malaria.

Today, Africans are integrating living with COVID-19 like all other common illnesses. Economically, if governments in some states have supported households, they have had to show resilience to live and survive during the pandemic: reduction in lifestyle, various loans (family and from formal and informal financial institutions like tontines) and deduction from their savings (for those who have them). But the effects suffered at the level of each country and of the African continent on the micro and macroeconomic levels cannot yet be fully assessed. Trying to alleviate the effects of the economic slump caused by COVID-19 has become the main concern of people in Africa, far from warning signs of potential new waves of contamination. Because, do we think in Africa that if the disease is there, and threatens to kill, hunger just as little easily continues its ravages in this continent already in the grip of various health, economic, security crises.

\section{References}

1. WHO (2020) WHO Director-General speech, Emergency Ministerial meeting on COVID-19 organized by the African Union and the Africa Centers for Disease Control and Prevention. 
ISSN: 2574-1241

DOI: $10.26717 /$ BJSTR.2020.30.004922

Paulin Bertrand NGUINA EKEME. Biomed J Sci \& Tech Res

(c) (P) This work is licensed under Creative

Submission Link: https://biomedres.us/submit-manuscript.php

$\begin{array}{ll}\text { BIOMEDICAL } & \text { Assets of Publishing with us } \\ \text { RESEARCHES } & \text { Global archiving of articles } \\ \text { - Immediate, unrestricted online access }\end{array}$

